\title{
Maatalouspolitiikan mahdollisuudet kasvihuonekaasupäästöjen vähentämisessä
}

\author{
Antti Simola \\ Helsingin Yliopisto, \\ Taloustieteenlaitos \\ Latokartanonkaari 9 \\ PL 27 \\ O0014 Helsingin Yliopisto \\ antti.simola@helsinki.fi
}

\section{Tiivistelmä:}

Ilmastonmuutos on suurin yksittäinen ympäristöongelma maailmassa tällä hetkellä. Vaikka sen vaikutuksiin liittyykin runsaasti epävarmuutta, on monissa maailman valtioissa päädytty hillitsemään ilmastonmuutosta. Taloudellisessa mielessä optimaalisesti toimiva yhteiskunnallinen suunnittelija pyrkii vähentämään päästöjä siellä missä se on kaikkein kustannustehokkainta. Tämä työ pyrkii pohtimaan kuinka tehokkaasti maatalouspolitiikan instrumenteilla voidaan vaikuttaa Suomen kasvihuonekaasupäästöjen syntyyn ja sitä kautta ilmastonmuutoksen hillitsemiseen.

Tutkimuksen teoreettinen pohja on uusklassisessa taloustieteessä ja omaa hyötyään maksimoivan rationaalisen taloudellisen toimijan oletuksessa. Tätä teoriapohjaa on laajennettu aiheen kannalta hyvin keskeisen ympäristötaloustieteen suuntaan. Ympäristötaloustieteelle ja saastumisen ongelmalle ovat keskeisiä ulkoisvaikutusten ja julkishyödykkeiden käsitteet. Tämän ongelman kannalta keskeisiä ovat myös globaalien saasteiden ongelma sekä hajapäästöjen ongelma.

Tutkimusmetodiksi valitsin työssäni ekonometrisen mallintamisen. Tutkimuksessa käytettiin koko EU:n kattavan AGMEMOD-mallin Suomen osamallia. Malli on näennäisesti rekursiivinen, osittain dynaaminen osittaisen tasapainon malli, jolla voidaan ennustaa Suomen maataloustuotannon kehitystä tärkeimpien tuotteiden osalta. Päivitin tätä perusmallia työssäni, laajensin sitä tietyiltä osin ja laadin siihen IPCC:n kasvihuonekaasujen laskentaohjeita vastaavan laskentataulukon. Tutkin mallilla viiden vaihtoehtoisen skenaarion suhdetta perusskenaariona toimineeseen Agenda 2000 skenaarioon. Vaihtoehtoiset skenaariot olivat: 1) vuoden 2003 YMP:n uudistus, 2) vapaa maailmankauppa, 3) teknologinen kehitys, 4) orgaanisten maiden poistaminen viljelyksestä ja 5) kolmen edellisen skenaarion yhdistelmä.

Viimeinen skenaario kuvasi eräänlaista maksimivähennyksen tapausta ja siinä saavutettiin $1 / 3$ vähennys perusskenaarioon verrattuna. YMP:n uudistus aiheutti hyvin vähäisen vähennyksen. Sen sijaan vapaa maailmankauppa ja teknologinen kehitys saivat aikaan tuntuvat vähennykset. Suurin yksittäinen vähennys saatiin aikaan poistamalla orgaaninen maa viljelyksestä. Tämä oli kuitenkin kaikkein kyseenalaisin skenaario johtuen useasta työssä tarkemmin eritellystä syystä. Maataloussektorilla saavutettava maksimivähennys on suuruudeltaan n. 11 \% Suomen vuonna 2003 Kioton päästötavoitteen ylittäneestä määrästä.

Asiasanat: Maatalous, ilmastonmuutos, uusklassinen taloustiede, ympäristötaloustiede, ekonometrinen mallintaminen 


\section{Johdanto}

Ilmastonmuutos on tällä hetkellä suurin yksittäinen ympäristöongelma maailmassa. Se on ainutlaatuinen myös globaalin laajuutensa vuoksi. Ilmastonmuutos kattaa ongelmana koko maapallon, jolla elämme. Ilmaston lämpeneminen on tiedemaailman enemmistön mielestä tosiasia, johon tulisi suhtautua vakavasti. Sen vaikutukset kohdistuvat kuitenkin eri lailla eri puolille maapalloa, vaikka yksittäisen päästöyksikön vaikutus ilmastonmuutokseen onkin kaikkialla sama. Tämän vuoksi erilaiset eturistiriidat ovat nousseet keskeisiksi esteiksi ratkaisun löytymiselle. Kaikkein suurimpia ongelmia on arveltu koituvan maapallon keskileveyksillä sijaitseville alueille, joissa kuivuuden lisääntyminen vaikuttaa satoihin negatiivisesti. Lisäksi joka puolella maapalloa alaville alueille koitunee ongelmia merenpinnan kohotessa. Kaikkein suurimman uhan tämä ympäristöongelma aiheuttaa tällöin nykyisin kehitysmaiksi luettaville maille, joissa asuu myös suurin osa maapallomme väestöstä.

Rikkaammatkaan maat eivät ole erityisessä turvassa tältä uhalta, minkä olemme voineet havaita esimerkiksi maailman tämän hetkisen taloushegemonian USA:n haavoittuvuudesta Karibian alueella riehuvien hirmumyrskyjen suhteen. Hirmumyrskyjen voimistuminen on nimittäin ilmastotieteilijöiden ennustama seuraus ilmaston lämpenemisestä. Lisäksi on otettava huomioon välilliset vaikutukset maailman taloudelle, jos oletetaan, että maapallon biologisesta tuotantopotentiaalista parhaimmat alueet tulevat uhatuiksi ja siirtyvät pallomme pinta-alaltaan suippenevia napoja kohden. Tällöin biologisen tuotantopotentiaalin pohjan voidaan nähdä huomattavasti kaventuvan. Tilanne pahenee entisestään, jos vielä kuvitellaan, että rannikoilla sijaitsevaa infrastruktuuria ja viljelysmaata tuhoutuu ja ihmisiä joutuu muuttamaan kohoavan merenpinnan tieltä. Monet tiedemiehet ovat itse asiassa arvioineet, että ilmastonmuutos on jo edennyt sellaisen pisteen ohi, jonka jälkeen sitä ei voida enää pysäyttää.

Suomen maatalouden kokemat epäsuotuisat luonnonolosuhteet ovat varmasti kaikkien tiedossa, ja tähän seikkaan ilmastonmuutos voisi joidenkin arvioiden mukaan tuoda jopa positiivisia muutoksia. Lisäksi maailmanmarkkinatilanteen huonontuminen voi mahdollisesti parantaa kotimaisen tuotannon kilpailukykyä. Epävarmuus on kuitenkin suurta, ja lisääntyvät kasvi- ja eläintaudit sekä tuholaisten parempi sopeutuminen viljelykasvien sopeutumiseen verrattuna ovat seikkoja, joiden vuoksi täkäläisen maatalouden parantuviin tuotantomahdollisuuksiin kannattaa suhtautua suurella varauksella.

Kansainvälisellä tasolla ongelmaa on pyritty lähestymään ns. Kioton sopimuksen avulla. Tämän kansainvälisen sopimuksen tarkoituksena on, että ilmastonmuutosta hillittäisiin vähentämällä ilmastonmuutosta aiheuttavien kasvihuonekaasujen päästöjä. Myös Suomi on mukana tässä sopimuksessa ja näkee siis kansakuntana, että sopimukseen osallistuminen on sen etujen mukaista. Vaikka suomalaiselle maataloustuotannolle voisi aiheutua potentiaalisia hyötyjä ilmastonmuutoksesta, on nähty, että uhat koko maailman taloudelle ja sopimuksessa mukanaolon tuoma positiivinen julkisuus (tai sopimuksesta pois jättäytymisestä koituvan negatiivisen julkisuuden välttäminen) riittävät kallistamaan kansakuntamme sopimuksessa mukanaolon puolelle. Koska Suomi tällä hetkellä selkeästi ylittää oman päästötavoitteensa (kuvio 1), on järkevää arvioida kaikkia mahdollisia keinoja, joilla tuohon tavoitteeseen voitaisiin päästä. Taloustieteellisten teorioiden mukaan yhteiskunnallisen päätöksentekijän tulee etsiä kustannustehokkaita ratkaisuja, jotta yhteiskunnan kannalta voitaisiin päätyä optimaaliseen ratkaisuun. Tämän vuoksi myös maatalouden päästöjen vähentämistä tulisi pohtia muiden sektorien ohessa, kun päästöjä vähennetään. Olen pyrkinyt tässä tutkimuksessa valottamaan, kuinka nämä mahdollisuudet ovat realisoitavissa ja minkälaisia mahdollisuuksia maataloussektorilla on osallistua Suomen päästötavoitteen saavuttamiseen. On selvää, että suurin vastuu asiassa edelleen lepää suurimman päästöjen aiheuttajan eli energiantuotannon harteilla, mutta myös maataloussektori voi tuoda lisähyötyä tähän prosessiin.

Epävarmuus on ilmastonmuutoksen osalta huomattava, mutta silti suurin osa maailman kansoista on päättänyt mieluummin varautua riskeihin ja lieventää niitä niin kauan kuin vain on vielä mahdollista. Pieni vähemmistö maapallon kansoista kuitenkin on ottanut vähättelevän kannan riskeihin. Nämä maat tuottavat kuitenkin eniten kasvihuonekaasujen päästöjä maailmassa henkeä kohden ja ovat siksi suuri este sopimuksen toiminnalle. On siis huomattava, että Kioton sopimus siinä muodossaan kuin se nykyisin on voimassa, ei ole vielä riittävä koko ongelman ratkaisemiseksi. Siksi sen jatkototeutus onkin hyvin keskeinen seikka ongelman selvittämisessä. 


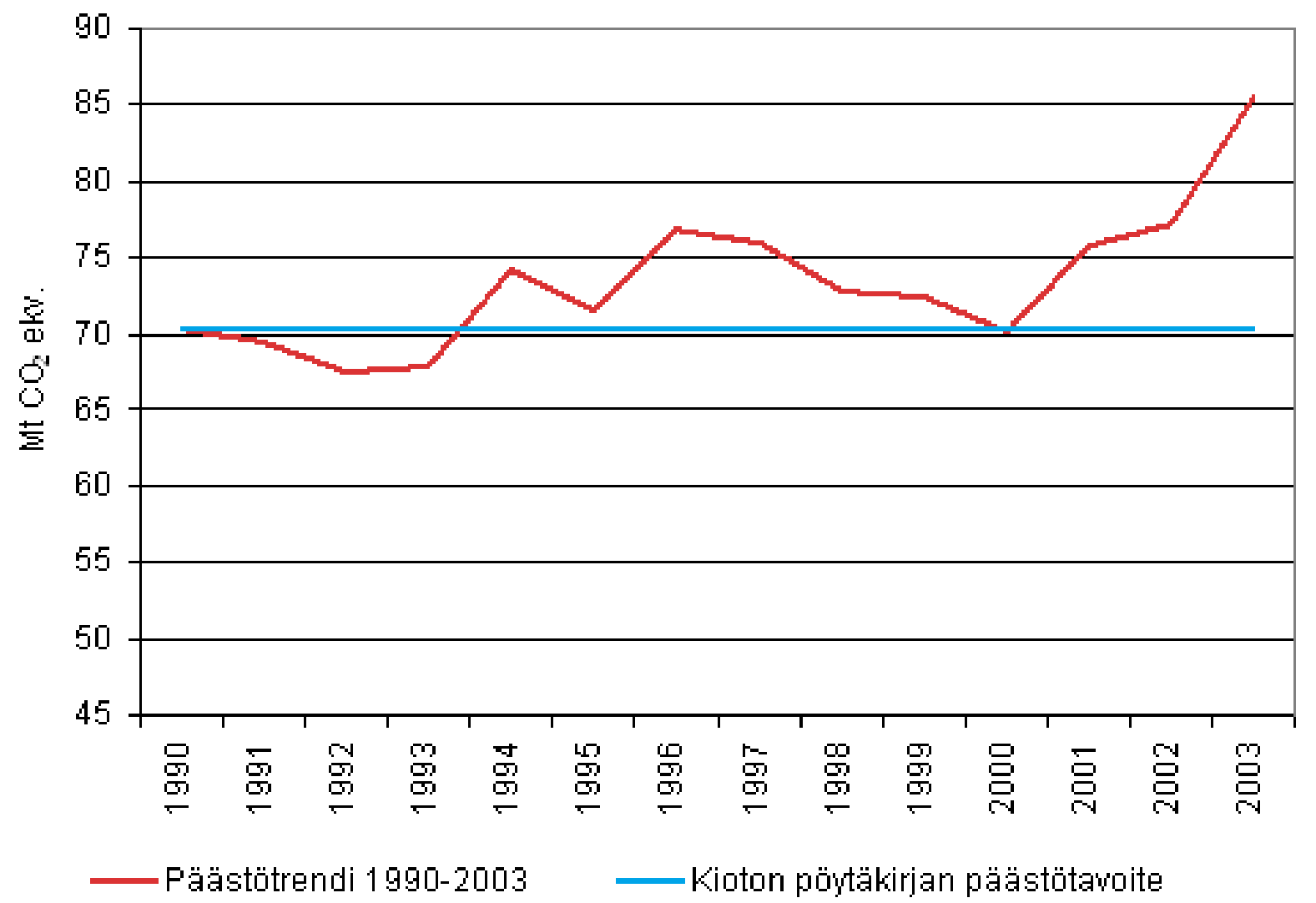

Kuvio 1. Kasvihuonekaasujen päästötrendi suhteessa Kioton pöytäkirjan tavoitteeseen (Tilastokeskus 2005).

\section{Tutkimusongelman tarkempi määrittely}

Maataloustuotannosta aiheutuu kolmen kasvihuonekaasun päästöjä, joilla on ilmaston lämpenemistä vahvistava vaikutus. Nämä kaasut ovat hiilidioksidi, dityppioksidi ja metaani. Kasvihuonekaasupäästöt lasketaan YK:n alaisen Hallitustenvälisen ilmastopaneelin IPCC:n laatimien laskukaavojen avulla (IPCC 1996). Nämä kaavat perustuvat parhaaseen mahdolliseen olemassa olevaan tieteelliseen tietoon, joka parhaimmassakin mahdollisessa tapauksessa on vielä jokseenkin epätäydellistä. Laskukaavoissa on olemassa vaihtoehtoja sen mukaan, minkälaista tietoa kyseisessä maassa on asian suhteen saatavilla. Lisäksi kaavoihin on laadittu ohjeelliset parametrit eri maanosille siltä varalta, että kansallista tutkimustietoa ei ole olemassa. Laskentamenetelmiä kehitellään jatkuvasti ja seuraava päivitys niihin on tulossa ensi vuonna. Hyvän yleiskuvan maatalouden kasvihuonekaasujen laskennasta siinä muodossa kuin ne on tässä tutkimuksessa huomioitu, saa lähteestä Kulmala ja Esala (2000).

Kokonaisuudessaan ilmastonmuutoksen kannalta merkittävin kasvihuonekaasu on hiilidioksidi, jota maataloudessa vapautuu maankäytön muutosten yhteydessä. Maata muokattaessa on tavallista, että maahan sitoutunutta hiiltä hajoaa ja vapautuu ilmakehään hiilidioksidina. Vapautuva määrä liittyy läheisesti maalajiin ja erityisesti maan sisältämään hiilidioksidin määrään. Mitä eloperäisempää maa on, sitä enemmän hiilidioksidia maasta viljelykäytössä vapautuu. IPCC:n ohjeissa maat jaetaan orgaanisiin ja kivennäismaihin. Orgaanisten maiden viljelyksestä aiheutuu ohjeiden mukaan hiilidioksidipäästöjä aina silloin, kun ne ovat viljelyksessä. Päästöjen intensiteetti riippuu siitä onko kyseinen maa turvemaata vai multamaata ja onko se viljan viljelyksessä vai nurmena. Kivennäismaiden osalta taas riippuu maanmuokkauksesta, kuinka paljon hiilidioksidia vapautuu. Esimerkiksi kyntömuokkaus aiheuttaa hiilidioksidin päästöjä kun taas suorakylvömenetelmillä voidaan saavuttaa hiilen sitoutumista maahan. Kivennäismaat voivat siis jopa viljelyksessä ollessaan ja oikein hoidettuina toimia hiilen nieluina ja auttaa ilmastonmuutoksen hillitsemisessä. Suomen maatalousmaasta $\mathrm{n} .13 \%$ on orgaanista maata ja loput kivennäismaata. Viimeisimmän kasvihuonekaasupäästöjen allokaation mukana hiilidioksidin päästöt siirrettiin pois maatalouden piiristä maankäytön ja metsätalouden kate- 
goriaan. Olen omassa tutkimuksessani noudattanut tätä uutta allokaatiota, ja hiilidioksidin päästöjä ei tämän vuoksi ole tässä tutkimuksessa arvioitu.

Dityppioksidi ja metaani ovat maataloustuotannolle tunnusomaisia kasvihuonekaasujen päästöjä ja maataloustuotanto on niiden suurin yksittäinen lähde. Muilla sektoreilla päästöt ovat yleensä keskittyneet lähinnä yhteen kaasuun, kun taas maataloudessa päästetään näitä kolmea kaasua kutakuinkin samassa suhteessa. Oman ongelmansa maatalouden kasvihuonekaasujen vähentämiseen tuo se, että jotkut toimet vähentäessään yhden kaasun päästöjä samalla lisäävät toisen kaasun päästöjä. Dityppioksidia pääsee maasta nitrifikaatio- ja denitrifikaatioprosessien yhteydessä. Nämä prosessit kiihtyvät yleensä hapettomissa oloissa, joka edistyy suorakylvön yhteydessä. Hiilidioksidin ja dityppioksidin samanaikainen vähentäminen maanmuokkauksen avulla voi olla tämän vuoksi ongelmallista. Myös dityppioksidin päästöt riippuvat siitä onko viljelty maa orgaanista vai kivennäismaata: orgaanisen maan aiheuttamat dityppioksidin päästöt ovat suuremmat kuin kivennäismaan. Dityppioksidia vapautuu myös kotieläintuotannon yhteydessä lannasta. Lannan käsittelyllä voidaan vaikuttaa siitä vapautuvan dityppioksidin määrään. Kaiken kaikkiaan dityppioksidi on voimakkain maatalouden tuottama kasvihuonekaasu. Yksi tonni dityppioksidia vastaa 310 tonnia hiilidioksidia kasvihuonevaikutukseltaan.

Metaani on myös hiilidioksidia voimakkaampi kasvihuonekaasu (1 tonni metaania on 21 tonnia hiilidioksidiekvivalentteina ilmaistuna). Sitä vapautuu jonkin verran myös maaperästä, mutta IPCC:n laskelmien mukaan sen verran vähän, että sen voi jättää huomiotta laskelmissa. Kotieläintuotanto on sen sijaan hyvin merkittävä metaanin päästäjä. Märehtijöiden suolistokaasujen päästöt ovat merkittävin metaanin lähde. Tähän voidaan pyrkiä vaikuttamaan eläinten ruokintaa tehostamalla. Myös lannankäsittelystä aiheutuu metaanin päästöjä, ja edelleen on merkittävää, että vähentämistoimet ovat epäsymmetrisiä lannasta aiheutuvien dityppioksidin päästöjen kanssa.

Päästöjen laskentaa kehitetään edelleen, ja oma kantani on tutkimuksessa ollut, että aloitettua maatalouden kasvihuonekaasupäästöjen uudelleen allokointia voisi jatkaa yhä edelleen. Raja olisi ehkä järkevintä asettaa maankäytön ja kotieläintuotannon välille nykyisen eri kaasujen välille tehdyn rajanvedon sijasta. Tällöin maankäytöstä aiheutuvat dityppioksidin päästöt siirrettäisiin maankäytön ryhmään, jolloin jäljelle jäävässä maatalouden ryhmässä olisi mukana ainoastaan kotieläintuotannon aiheuttamat päästöt. Vaikka näilläkin päästölähteillä on omat kiinteät yhteytensä, vaikuttaisi kuitenkin siltä, että tässä tapauksessa ei kuitenkaan ole yhtä paljon limittyneisyyttä tuotantohaarojen välillä kuin nykyisin käytössä olevassa systeemissä. Lisäksi maankäytön kilpailevat muodot ja elintarvikkeiden erilaiset kulutustottumukset tulisivat selkeämmin jaoteltua, mikä taas helpottaisi päätöksentekoa.

Maataloustuotanto aiheuttaa kasvihuonekaasujen päästöjä, ja maataloustuotantoon vaikuttaa puolestaan toteutettu maatalouspolitiikka. EU:n yhteiseen maatalouspolitiikkaan YMP:aan ei sinänsä ole sisältynyt ilmastonmuutoksen hillitsemiseen tähtääviä tavoitteita tai toimia. Voidaan kuitenkin nähdä, että esimerkiksi viimeisimmän uudistuksen mukana käyttöön otetut tukioikeuksien täydentävät ehdot viljelymaan viljelykunnon säilyttämisestä voivat potentiaalisesti vähentää päästöjä. Maatalouden tuottamat kasvihuonekaasujen päästöt ovat olleet jo pitkään laskevalla uralla, ja tähän voidaan löytää pääasiassa kaksi syytä: toisaalta tuotannon väheneminen ja toisaalta sen tehostuminen. Molempiin on osaltaan vaikuttanut YMP. Tuotanto on käynyt kannattamattomammaksi, ja esimerkiksi kotieläinten määrä on laskenut YMP:aan siirtymisen jälkeen. Lisäksi pienemmät ja epävakaammat tulot ovat antaneet kannustimen viljelijöille vähentää tuotantokustannuksia ja siten myös tehostaa tuotantoaan. Hyvän yleisesityksen Suomen maatalouden kasvihuonekaasupäästöjen kehityksestä antaa MMM (2001) työryhmämuistiossaan. MMM on myös hiljattain laatinut ilmastonmuutoksen varalta strategian, jossa keskitytään ilmastonmuutokseen varsin kattavasti nimenomaan sen vaikutusten ja sopeutumisen varalta (MMM 2005).

\section{Tutkimusmetodi ja sen käyttö}

Vaikka maatalouspolitiikalla ei olekaan ollut aktiivista roolia ilmastonmuutoksen hillitsemisessä, on kuitenkin selvää, että sillä on omat merkittävät vaikutuksensa. Olen tutkimuksessani pyrkinyt kartoittamaan, kuinka maatalouspolitiikan eri instrumenteilla voidaan vaikuttaa maataloustuotannosta syntyviin kasvihuonekaasujen päästöihin. Eri politiikkainstrumenttien vertailu tapahtui Suomen maataloussektoria kuvaavan AGMEMOD-mallin avulla. Tämän mallin antamat tuotantomäärät syötin kasvihuonekaasupäästöt laskevaan taulukkoon; se taas oli laadittu edellä mainittujen IPCC:n ohjeiden mukaan. AGMEMOD-malli antaa Suomen maataloussektorin vuosittaiset tuotostasot vuoteen 2010 asti, ja tuohon ajankohtaan asti ulottuvat myös 
tutkimuksessa tekemäni ennusteet. Perusasetelma mallissa oli Agenda 2000:n mukainen YMP, jota sitten verrattiin muutamaan vaihtoehtoiseen politiikkaskenaarioon. Ensimmäisenä vaihtoehtoisena skenaariona oli vuoden 2003 reformin mukaisin hinnoin toteutuva tuotanto ja toisena samaan kategoriaan kuuluvana skenaariona vapaan maailmankaupan skenaario, jossa maailmanmarkkinahinnat asetettiin vallitsemaan Suomen sisämarkkinoille. Nämä olivat siis puhtaasti hintojen muutoksien vaikutuksia kuvaavia skenaarioita.

Kolmas vaihtoehtoskenaario havainnollisti teknologiseen kehitykseen panostamisen mahdollisuuksia päästöjen vähentämisessä. Tämä liittyy ns. indusoidun teknologisen kehityksen ajatukseen, jossa tarkastellaan sitä, kuinka valtiovallan toimien avulla voidaan kannustaa teknologista kehitystä ja siten vähentää teknologista kehitystä hidastavia ulkoisvaikutuksia. Mallinnusteknisistä syistä ja teknologisen kehityksen lukuisten mahdollisuuksien takia rajoitin tämän skenaarion koskemaan ainoastaan nautakarjan ruokinnan tehostamisesta mahdollisesti koituvia hyötyjä. Neljäntenä vaihtoehtoisena skenaariona käytin orgaanisten maiden viljelystä poistamisen ideaa. Hyvin usein maatalouden kasvihuonekaasupäästöjen yhteydessä esitetty ajatus on, että koska turvemaat ovat suurin yksittäinen päästöjen lähde, voitaisiin saavuttaa merkittävä päästöjen vähennys jo pelkästään ottamalla nämä maat pois viljelyksestä. Koska orgaanisia maita ei dityppioksidin osalta ole eroteltu turve- ja multamaihin erikseen, jouduin olettamaan kaikkien orgaanisten maiden viljelystä poistamisen, vaikka tämä skenaariona onkin varsin epärealistinen. Viimeinen skenaario oli yhdistelmä vaihtoehtoskenaarioista kaksi, kolme ja neljä.

\section{Tutkimuksen tuloksia}

Tutkimukseni ei tuottanut erityisen yllättäviä tuloksia, ja päästöjen suunta vastaa hyvin aikaisemmissa tutkimuksissa (esim. Pipatti, ym. 2000 ja MMM 2001) havaittua ja se on trendiltään laskeva. Eri skenaarioiden osalta voidaan sanoa, että vuoden 2003 YMP:n uudistus aiheuttaa vain pienen laskun Agenda 2000:n mukaisiin päästöihin verrattuna. Maailmankaupan vapauttaminen aiheuttaa jo huomattavasti suuremman laskun päästöissä, mikä oli helposti odotettavissa. Teknologisen kehityksen kannustamisella sain mallissa markkinoiden avaamista pienemmän, mutta silti selkeästi havaittavissa olevan laskun päästöissä. Tämä on omasta mielestäni kuitenkin vahvasti positiivinen tulos, sillä kuten jo edellä huomautin, sisältyy tähän skenaarioon vain hyvin pieni osa kaikesta teknologisen kehityksen potentiaalista. Selvästi suurimman vaikutuksen toi odotetusti orgaanisten maiden viljelystä poistaminen. Maailmankaupan vapauttamisen, teknologisen kehityksen ja orgaanisten maiden poiston yhteisskenaarion avulla saatiin eräänlaista maksimaalista päästöjen vähennystä kuvaava tilanne, ja siinä päästöt päätyvät vuonna 2010 2/3:ksi tasoon Agenda 2000:n vastaavana vuonna saavuttamasta tasosta. Yhteensä tämä on 11,1 \% Suomen vuonna 2003 Kioton päästötavoitteen ylittäneistä päästöistä eli päästöjen vähennyksen tarpeesta. Päästöoikeuksien hinnalla mitattuna tämä maksimivähennys on 39 miljoonan euron arvoinen, ja tämä vähennyksen arvo on taas n. $2 \%$ koko Suomen maataloussektorin tuottamasta bruttokansantuotteesta (vuoden 2003 arvosta). Kuviosta 2 käyvät ilmi mallin antamat päästöjen urat eri skenaarioissa.

\section{Johtopäätökset}

Johtopäätöksenä tutkimuksen tuloksista voidaan sanoa, että maatalouspolitiikalla voidaan jonkin verran vaikuttaa myös kasvihuonekaasupäästöjen muodostumiseen. Siten maatalouspolitiikan tulee olla mukana kansallisessa keskustelussa ilmastonmuutoksen hillitsemisestä puhuttaessa. Kokonaisuuden kannalta nämä vähennykset kannattaa toteuttaa, jos kustannustehokas ratkaisu löytyy. Teknologisen kehityksen avulla on suurimmat mahdollisuudet päästä tähän jopa negatiivisilla kustannuksilla ja siksi valtiovallan tukitoimia olisi järkevää ohjata teknologisen kehityksen edistämiseen. On myös otettava huomioon nykyisin vilkkaan keskustelun piirissä oleva maatalouden vientitukien poisto, jolla on päästöjä vähentävä vaikutus ja josta on potentiaalisesti myös kansantaloudellisia tehokkuushyötyjä, kun asiaa ajattelee hyvinvointitaloustieteen näkökulmasta. Orgaanisten maiden poistoon tuskin kannattaa kuitenkaan ryhtyä ainakaan aktiivisessa mielessä, vaan tämän voisi ennemminkin antaa tapahtua omalla painollaan. Turvemaiden viljelyyn otolle tulisi sen sijaan asettaa esteitä ja mahdollisia palkkioita voisi harkita turvemaiden onnistuneesta metsittämisestä. 


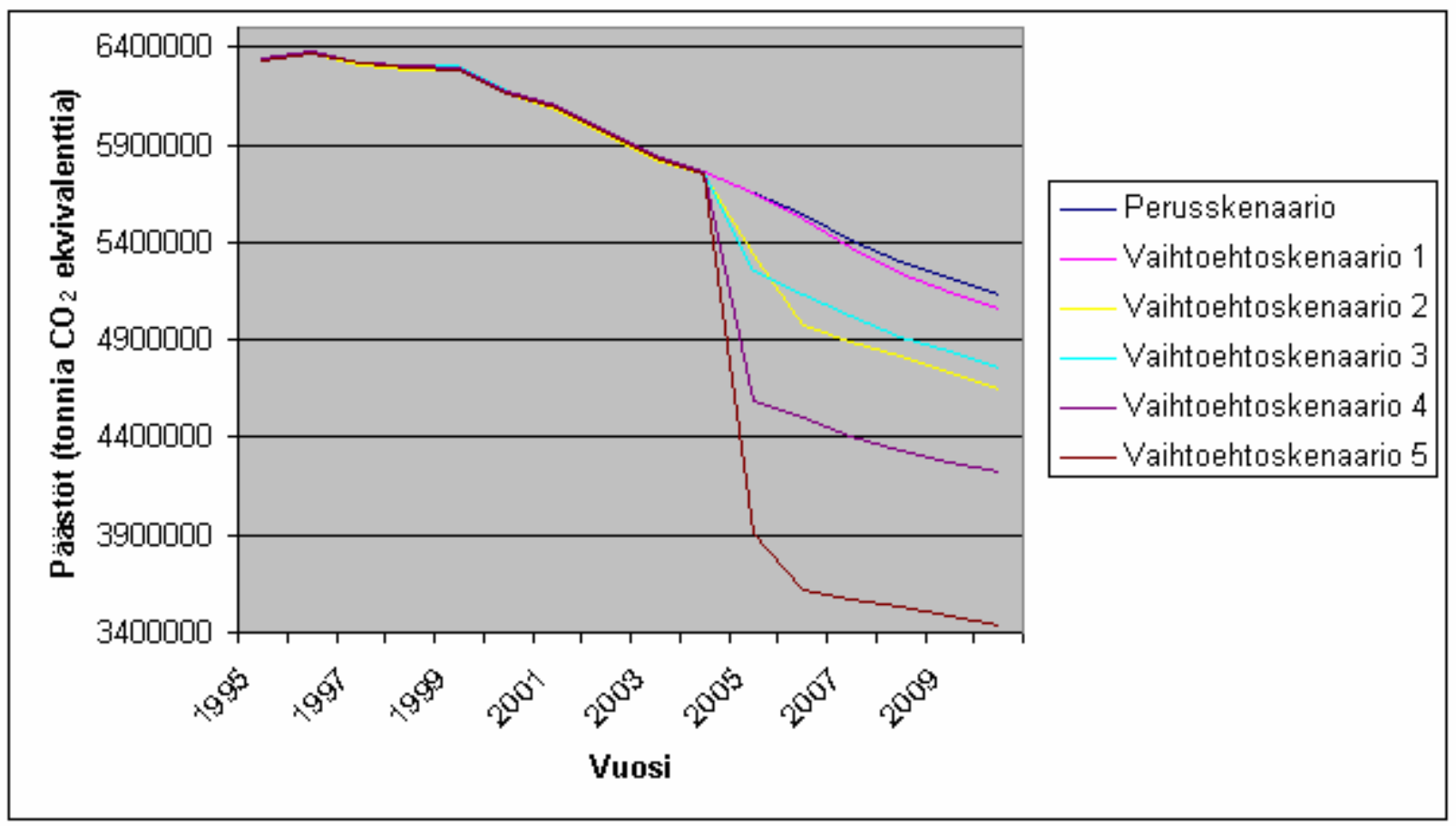

Kuvio 2. Kokonaispäästöjen urat eri skenaarioissa.

Maataloussektorin ottaminen mukaan päästöjen vähennykseen päästöoikeuksien kaupan yhteydessä on varmasti hyvin hankalasti toteutettavissa. Maatalouden päästöt ovat hajapäästöjä, vaihtelu on suurta alueiden välillä ja jopa myös tilojen sisällä sekä päästöjen laskentaan liittyy suuri epävarmuus. Sektoritasolla päästöoikeuksien kauppaan liittymistä voisi kuitenkin myös jossain määrin harkita teknologisen kehityksen vaatimien pääomien hankkimiseksi. Päästökauppa vaikuttaa tulevaisuudessa kuitenkin epäsuorasti myös maataloustuotantoon, jos ajatellaan uusiutuvan energiantuotannon hyötyvän päästöoikeuksien hintojen noususta.

Pääpaino maatalouden ilmastonmuutoskeskustelussa tulee mielestäni myös jatkossa olla ilmastonmuutokseen sopeutumisessa ja uusiutuvan energian tuotannossa. Näiden ohella hillitsemistä tulee kuitenkin tarkastella omana osanaan ja myös osana sopeutumista ja uusiutuvan energian tuotantoa. Kuten on jo todettu, tulee myös luonnontieteellistä ilmastonmuutoksen tutkimusta ja päästöjen luokittelua kehittää edelleen. Näin voidaan varmistaa ajanmukaisen tiedon saatavuus sekä päästöjen laskennan parempi tarkoituksenmukaisuus, joiden avulla yhteiskunnallinen suunnittelu voi saada paremmin tarkoituksiinsa soveltuvaa tietoa.

\section{Kirjallisuusluettelo:}

IPCC 1996. Revised 1996 Guidelines for National Greenhouse Gas Inventories. London: IPCC, OECD \& IEA. Vol. 13. myös http://www.ipcc-nggip.iges.or.jp/public/gl/invs1.htm

IPCC 2001. Climate Change 2001 - Synthesis report. Cambridge, Cambridge University Press, 392 p.

Kulmala, A. \& Esala, M. 2000. Maatalous ja kasvihuonekaasupäästöt. Kirjallisuuskatsaus. Maatalouden tutkimuskeskuksen julkaisuja. Sarja A, 76. 67 s.

MMM 2001. Maatalouden kehitysarvio kansallista ilmasto-ohjelmaa varten. Työryhmämuistio MMM 2001:2. Maa- ja metsätalousministeriö. 48 s.

MMM 2005. Ilmastonmuutoksen kansallinen sopeutumisstrategia. MMM:n julkaisuja 1/2005. 276 s. 
Pipatti, R., Tuhkanen, S., Mälkiä, P. \& Pietilä, R. 2000. Maatalouden kasvihuonekaasupäästöt sekä päästöjen vähentämisen mahdollisuudet ja kustannustehokkuus. VTT julkaisuja $841.72 \mathrm{~s}$.

Tilastokeskus 2005. Vuoden 2003 viralliset kasvihuonekaasupäästömäärät YK:n ilmastosopimukselle. http://www.tilastokeskus.fi/til/khki/index.html 